\title{
Body mass index and survival after breast cancer diagnosis in Japanese women
}

\author{
Masaaki Kawai ${ }^{1,4^{*}}$, Yuko Minami ${ }^{1 \dagger}$, Yoshikazu Nishino ${ }^{2 \dagger}$, Kayoko Fukamachi $^{3 \dagger}$, Noriaki Ohuchi ${ }^{4 \dagger}$ and \\ Yoichiro Kakugawa ${ }^{3+}$
}

\begin{abstract}
Background: Body mass index (BMI) may be an important factor affecting breast cancer outcome. Studies conducted mainly in Western countries have reported a relationship between higher BMI and a higher risk of all-cause death or breast cancer-specific death among women with breast cancer, but only a few studies have been reported in Japan so far. In the present prospective study, we investigated the associations between BMI and the risk of all-cause and breast cancer-specific death among breast cancer patients overall and by menopausal status and hormone receptor status.
\end{abstract}

Methods: The study included 653 breast cancer patients admitted to a single hospital in Japan, between 1997 and 2005. BMI was assessed using a self-administered questionnaire. The patients were completely followed up until December, 2008. Hazard ratios (HRs) and 95\% confidence intervals (Cls) were estimated according to quartile points of BMl categories, respectively: $<21.2, \geq 21.2$ to $<23.3$ (reference), $\geq 23.3$ to $<25.8$ and $\geq 25.8 \mathrm{~kg} / \mathrm{m}^{2}$.

Results: During the follow-up period, 136 all-cause and 108 breast cancer-specific deaths were observed. After adjustment for clinical and confounding factors, higher BMI was associated with an increased risk of all-cause death $\left(\mathrm{HR}=2.61 ; 95 \% \mathrm{Cl}: 1.01-6.78\right.$ for $\mathrm{BMl} \geq 25.8 \mathrm{vs}$. $\geq 21.2$ to $\left.<23.3 \mathrm{~kg} / \mathrm{m}^{2}\right)$ among premenopausal patients. According to hormonal receptor status, BMI $\geq 25.8 \mathrm{~kg} / \mathrm{m}^{2}$ was associated with breast cancer-specific death ( $\mathrm{HR}=4.95 ; 95 \%$ Cl: $1.05-$ 23.35) and $\mathrm{BMI}<21.2 \mathrm{~kg} / \mathrm{m}^{2}$ was associated with all-cause ( $\left.\mathrm{HR}=2.91 ; 95 \% \mathrm{Cl}: 1.09-7.77\right)$ and breast cancer-specific death ( $H R=7.23 ; 95 \% \mathrm{Cl}: 1.57-33.34)$ among patients with $E R+$ or PgR + tumors. Analysis by hormonal receptor status also showed a positive association between BMl and mortality risk among patients with $\mathrm{ER}+$ or PgR + tumors and with $\mathrm{BMI} \geq 21.2 \mathrm{~kg} / \mathrm{m}^{2}$ ( $p$ for trend: 0.020 and 0.031 for all-cause and breast cancer-specific death, respectively).

Conclusions: Our results suggest that both higher BMI and lower BMl are associated with an increased risk of mortality, especially among premenopausal patients or among patients with hormonal receptor positive tumors. Breast cancer patients should be informed of the potential importance of maintaining an appropriate body weight after they have been diagnosed.

Keywords: Breast cancer, Survival, Body mass index, Hormone receptor, Menopausal status

\section{Background}

Many previous epidemiologic studies have demonstrated that higher body mass index (BMI) is associated with an increased risk of postmenopausal breast cancer, whereas it is associated with a reduced risk of premenopausal breast cancer [1]. Furthermore, some

\footnotetext{
* Correspondence: kawai@med.tohoku.ac.jp

${ }^{\dagger}$ Equal contributors

'Division of Community Health, Tohoku University Graduate School of Medicine, 2-1 Seiryo-machi, Aoba-ku, Sendai, Miyagi980-8575, Japan ${ }^{4}$ Department of Surgical Oncology, Tohoku University Graduate School of Medicine, 1-1 Seiryo-machi, Aoba-ku, Sendai, Miyagi980-8574, Japan Full list of author information is available at the end of the article
}

studies conducted mainly in Western countries have found associations between higher BMI and a higher risk of all-cause death [2-10] or breast cancer-specific death $[6,11,12]$ among women with breast cancer, although other studies have found no such association [13-16]. As various inconsistencies have been reported across menopausal status between BMI and survival among premenopausal $[2,4,8,12,17-21]$ and postmenopausal women $[5,8,11,12,21]$, it is important to stratify menopausal status in order to adequately assess the relationship between BMI and mortality of breast cancer patients.

\section{Biomed Central}


In adipose tissue, conversion of androgens to estrogens by aromatase occurs [22]. Estrogen accelerates breast tumor growth via the estrogen receptor. Breast tumors have estrogen or progesterone receptors, and tumor subtypes defined by these receptors may represent biologically different entities [23,24] and influence the survival of patients. Therefore it seems important to consider tumor subtypes when evaluating the relationship between BMI and mortality due to breast cancer, and in fact several studies have already investigated the effects of tumor subtype in terms of hormone receptor status $[2,4,9,10,13,14,20]$.

In Japan, two previous studies have assessed the relationship between BMI and survival in breast cancer patients $[25,26]$. However, those studies were small in scale and controlled for only a few known risk factors. Only one previous study has addressed this issue in terms of menopausal status [26], but no attempt has yet been made to do so in terms of hormone receptor status.

In the present study, therefore, we investigated the relationship between BMI and the risk of all-cause death and breast cancer-specific death among breast cancer patients in terms of menopausal status and also hormone receptor status using a hospital-based prospective cohort study. Some known risk factors, tumor stage, and data on the therapy used for breast cancer were taken into account as covariates. Analyses stratified according to menopausal and hormone receptor status were performed, along with analysis of the patients overall.

\section{Methods}

\section{Study subjects}

Between January 1997 and December 2005, 718 female patients aged 29 years or over were newly diagnosed as having breast cancer at the Miyagi Cancer Center Hospital $(\mathrm{MCCH})$. All of these patients were requested to complete a questionnaire upon initial admission. After diagnosis, their details were entered into the hospitalbased cancer registry and the patients were followed up. This cancer registry recorded clinical and pathological findings and information on antineoplastic treatments for all patients with cancer admitted to the $\mathrm{MCCH}$. The $\mathrm{MCCH}$ is located in Natori City, situated in the southern part of Miyagi Prefecture. It has 383 administrative beds, and functions as both a general hospital and a comprehensive research institute for both all types of cancer and benign diseases.

Among the 718 newly diagnosed breast cancer patients, 664 (92.5\%) completed the questionnaire. After excluding 7 patients with a history of cancers other than breast cancer, the 657 remaining patients were included in the present study, which was approved by the ethical review board of Miyagi Cancer Center.

\section{Questionnaire and clinical information}

In January 1997, we began a survey in connection with the present study. Information on lifestyle and personal history was collected from all patients using a self-administered questionnaire, which was distributed to patients on the day of their reservation for initial admission to the $\mathrm{MCCH}$, i.e., 10-15 days before admission, and collected by nurses on the actual admission day. Details of the questionnaire survey have already been described elsewhere $[27,28]$.

The questionnaire covers items on demographic characteristics, current height and weight, family histories of cancer and other diseases, general lifestyle factors before the development of current symptoms including history of smoking, menopausal status, and comorbidity of other diseases.

Clinical information including tumor stage and treatment, such as chemotherapy, radiation therapy and endocrine therapy, was obtained from the MCCH hospital-based cancer registry. Information on hormone receptor status, i.e. expression of the estrogen receptor (ER) and progesterone receptor (PgR), was extracted from medical records. To measure ER and PgR status, enzyme immunoassay (EIA) was used in the early period of the study. After mid-2003, immunohistochemistry (IHC) was conducted. The cut-off point for receptor positivity in the EIA was $14 \mathrm{fmol} / \mathrm{mg}$ for ER and 13 $\mathrm{fmol} / \mathrm{mg}$ for PgR. In the IHC assay, a histology score (HSCORE) of $\geq 20$ for ER and one of $\geq 6$ for PgR were evaluated as positive [29]. The concordance between the two assays was $94.3 \%$ for ER and $100 \%$ for PgR in the laboratory of the MCCH [29]. Receptor status was unknown for ER in 69 cases (10.5\%), PgR in 80 (12.2\%) cases, and both in $69(10.5 \%)$ cases. 392 (59.7\%) cases were ER + and 318 (48.4\%) were PgR + .

\section{Ascertainment of exposures and follow-up}

At the $\mathrm{MCCH}$, initial therapy is administered after admission in principal. Therefore, data on weight and height collected using the questionnaire was considered to be pretreatment data. BMI was calculated as weight divided by the square of current height $\left(\mathrm{kg} / \mathrm{m}^{2}\right)$. Height and weight were measured by medical staff in a subsample $(n=315)$ of our study at the time of initial hospital admission. The self-reported height and weight data were highly correlated with the measured data (correlation coefficient: 0.94 for height and 0.96 for weight). Four patients for whom BMI values were missing were excluded, leaving a final total of 653 patients for analysis. We stratified the patients according to BMI quartile points: $<21.2 \mathrm{~kg} / \mathrm{m}^{2}, \geq 21.2 \mathrm{~kg} / \mathrm{m}^{2}$ to $<23.3 \mathrm{~kg} / \mathrm{m}^{2}$, $\geq 23.3 \mathrm{~kg} / \mathrm{m}^{2}$ to $<25.8 \mathrm{~kg} / \mathrm{m}^{2}$ and $\geq 25.8 \mathrm{~kg} / \mathrm{m}^{2}$. The BMI category $\geq 21.2 \mathrm{~kg} / \mathrm{m}^{2}$ to $<23.3 \mathrm{~kg} / \mathrm{m}^{2}$ was selected as the reference. 
Follow-up was performed by reference to the $\mathrm{MCCH}$ Cancer Registry up to December 31, 2008. Active followup was conducted by accessing hospital visit records, resident registration cards and permanent domicile data. Information on the dates and causes of death was obtained with permission from the Ministry of Justice. During the study period, no subject was lost to followup.

\section{Statistical analysis}

The end point of our analysis was all-cause death and breast cancer-specific death according to the International Classification of Disease for Oncology, Tenth Edition (ICD-10). Survival time was calculated for each patient from the date of diagnosis to the date of death or the end of follow-up (December 31, 2008).

The Cox proportional hazards model was used to estimate hazard ratios (HRs) and 95\% confidence intervals (CIs) for all-cause death and breast cancer-specific death in relation to BMI [30]. Tests for trend were employed in the Cox model for all BMI categories and for $\geq 21.2 \mathrm{~kg} / \mathrm{m}^{2}$ respectively, because we expected the overall relationship of BMI to mortality to be U-shaped rather than linear (i.e., we expected women with BMI $<21.2 \mathrm{~kg} / \mathrm{m}^{2}$ have higher mortality than the reference category). We considered the following variables to be potential confounders: age, tumor stage (in situ or localized, local invasion, lymph node metastasis, distant metastasis), hormone receptor status (ER + or PgR+, ER-/ PgR-), radiation therapy (no, yes), chemotherapy (no, yes), endocrine therapy (no, yes) and comorbidities (no, yes). Comorbidities included hypertension, ischemic heart disease, stroke and diabetes mellitus. Smoking (current, past, never), family history of breast cancer in mother or sister (no, yes), and physical activity (almost no, more than one hour per week, missing), some of which have already been established as risk factors for breast cancer, were also considered to be adjusted for [31-33]. Missing values for confounders were treated as an additional variable category, and included in the model.

Separate analyses were conducted after dividing the patients according to premenopausal or postmenopausal status, along with analysis of the patients overall. Stratification according to hormonal receptor status was also performed. To evaluate heterogeneity of the associations between BMI and all-cause death and breast cancer-specific death across menopausal status (premenopausal vs. postmenopausal) and hormone receptor status (ER + or PgR + vs. ER-/PgR-), interaction terms (BMI * menopausal status, BMI * hormone receptor status) were tested. Likelihood ratio tests were used to assess the significance of heterogeneity by comparing the model including the interaction term to the main-effects model.
Menopause was defined as the cessation of menstrual periods due to natural or other reasons, including surgery. With regard to menopause due to other reasons, we were unable to obtain any information about history of oophorectomy; therefore, patients 44-57 years of age (defined as the mean age at natural menopause $\pm 2 \mathrm{SD}$ ) were regarded as having unknown menopausal status.

Results were regarded as significant if the two-sided $\mathrm{P}$ values were $<0.05$. All statistical analyses were performed using the SAS software package (version 9.2; SAS Institute, Cary, NC).

\section{Results}

During a median follow-up period of 5.85 years, 136 allcause and 108 breast cancer-specific deaths were observed. The characteristics of the patients at the time of breast cancer diagnosis are shown in Table 1. Heavier patients tended to have hormonal receptor-positive tumors. With regard to hormone receptor status, 410 (62.8\%) cases were $\mathrm{ER}+$ or PgR+, and 174 (26.6\%) were ER-/PgR-. Women with higher BMI were more likely to be older, to be postmenopausal, to exercise more, to have more comorbidities, and to have hormone receptor-positive tumors.

Table 2 shows the association of BMI with all-cause death. Compared to women with BMI $\geq 21.2$ to $<23.3 \mathrm{~kg} / \mathrm{m}^{2}$, those with BMI $<21.2 \mathrm{~kg} / \mathrm{m}^{2}$ were shown to have a higher risk of death by age-adjusted analysis ( $\mathrm{HR}=1.73$, 95\% CI: 1.07-2.80), but not by multivariateadjusted analyses (1.60, 0.97-2.63). No dose-response relationship was observed between BMI and all-cause death (multivariate-adjusted $\mathrm{p}$ for trend $=0.59$ ). Analysis limited to women with BMI $\geq 21.2 \mathrm{~kg} / \mathrm{m}^{2}$ also demonstrated no dose-response relationship (multivariateadjusted $\mathrm{p}$ for trend $=0.11$ ). Stratification by menopausal status yielded inconsistent results. BMI had no significant association with all-cause death among postmenopausal women, whereas a significantly increased risk of all-cause death was found among premenopausal obese women (BMI $\geq 25.8 \mathrm{~kg} / \mathrm{m}^{2}$ ) in both age-adjusted (2.49, 1.03-6.03) and multivariate-adjusted analyses (2.61, 1.01-6.78). For premenopausal women with BMI $\geq 21.2 \mathrm{~kg} / \mathrm{m}^{2}$, trend test demonstrated a marginal doseresponse relationship between BMI and all-cause death (multivariate-adjusted $\mathrm{p}$ for trend $=0.059$ ). The trends were not significantly different between premenopausal and postmenopausal women with $\mathrm{BMI} \geq 21.2 \mathrm{~kg} / \mathrm{m}^{2}$ ( $\mathrm{P}$ for heterogeneity of trends $=0.11$ ).

With regard to breast cancer-specific death, ageadjusted analysis and multivariate-adjusted analysis showed that women with BMI $<21.2 \mathrm{~kg} / \mathrm{m}^{2}$ were not at higher risk (Table 3). No dose-response relationship between BMI and breast cancer-specific death was found.

Analysis stratified by hormonal receptor status demonstrated differences in the risk of death across strata for 
Table 1 Characteristics of the study cohort

\begin{tabular}{|c|c|c|c|c|c|}
\hline & $\begin{array}{l}\text { BMI } \\
<21.2\end{array}$ & $\geq 21.2$ to $<23.3$ & $\geq 23.3$ to $<25.8$ & $\geq 25.8$ & Total \\
\hline Age (years) mean \pm S.D. & $53.7 \pm 13.4$ & $55.2 \pm 11.2$ & $58.9 \pm 12.0$ & $60.0 \pm 11.9$ & $57.0 \pm 12.4$ \\
\hline Person-years & 963.0 & 1052.4 & 1020.1 & 997.3 & 4032.8 \\
\hline Patients (n) & 163 & 166 & 161 & 163 & 653 \\
\hline All-cause death (n) & 42 & 27 & 29 & 38 & 136 \\
\hline Breast cancer-specific death ( $\mathrm{n}$ ) & 34 & 21 & 26 & 27 & 108 \\
\hline \multicolumn{6}{|l|}{ Smoking (\%) } \\
\hline Never & 72.4 & 78.9 & 85.7 & 82.2 & 79.8 \\
\hline Current or Past & 25.2 & 17.5 & 12.4 & 14.1 & 17.3 \\
\hline Missing & 2.5 & 3.6 & 1.9 & 3.7 & 2.9 \\
\hline
\end{tabular}

Stage (\%)

In situ or Locarized
Lymph node Metastasis
Local Invasion
Distant Metastasis
Missing

Hormone receptor (\%)

$$
\begin{aligned}
& \mathrm{ER}+\text { or PgR+ } \\
& \text { ER-/PgR- } \\
& \text { Missing }
\end{aligned}
$$

Radiation therapy (\%)

$\begin{array}{ll}\text { No } & 77.3 \\ \text { Yes } & 22.7\end{array}$

Chemotherapy (\%)

No

Yes

$$
74.8
$$

Yes

Menopausal status (\%) ${ }^{a}$

$$
\begin{aligned}
& \text { Premenopausal } \\
& \text { Postmenopausal } \\
& \text { Missing }
\end{aligned}
$$

Physical activity (\%)

$$
\begin{aligned}
& \text { Almost no } \\
& \text { More than one hour per week } \\
& \text { Missing }
\end{aligned}
$$

Comorbidities (\%) ${ }^{b}$

$$
\begin{array}{cccc}
\text { No } & 86.5 & 80.1 & 71.4 \\
\text { Yes } & 13.5 & 19.9 & 28.6 \\
\hline \text { a Menopause was defined as the cessation of menstrual periods due to natural or other reasons including surgery. } \\
\text { b Includes hypertension/ischemic heart disease/stroke/diabetes mellitus. } \\
\text { During a median follow-up period of } 5.85 \text { years, } 136 \text { all-cause and } 108 \text { breast cancer-specific deaths were observed. }
\end{array}
$$

43.4
34.9
6.6
2.4
12.7

34.2

41.6

9.9

5.0

9.3

65.2

25.5

9.3

86.3

13.7

75.2

24.8

79.5

20.5

90.7

9.3

39.1

57.8

3.1

45.3

46.0

8.7

7.2

\section{3}

$$
35.6
$$

8.0

3.1

14.1

39.2

35.7

8.7

3.1

13.3

69.3

62.8

22.7

26.6

8.0

10.6 
Table 2 HR $(95 \% \mathrm{Cl})$ of all-cause death associated with BMI overall and by menopausal status

\begin{tabular}{|c|c|c|c|c|c|c|c|c|c|}
\hline BMI & Patients & $\begin{array}{l}\text { Person- } \\
\text { years }\end{array}$ & $\begin{array}{l}\text { All-cause } \\
\text { death }\end{array}$ & $\begin{array}{l}\text { Age- } \\
\text { HR }\end{array}$ & $\begin{array}{l}\text { djusted } \\
95 \% \mathrm{Cl}\end{array}$ & & $\begin{array}{l}\text { Mult } \\
\text { HR }\end{array}$ & $\begin{array}{l}\text { ariate-adjustec } \\
95 \% \mathrm{Cl}\end{array}$ & \\
\hline All & & & & & & & & & \\
\hline$<21.2$ & 163 & 963.0 & 42 & 1.73 & $1.07-2.80$ & & 1.60 & $0.97-2.63$ & \\
\hline$\geq 21.2$ to $<23.3$ & 166 & 1052.4 & 27 & 1.00 & eference) & & 1.00 & ference) $^{a}$ & \\
\hline$\geq 23.3$ to $<25.8$ & 161 & 1020.1 & 29 & 1.03 & $0.61-1.75$ & & 0.88 & $0.51-1.51$ & \\
\hline$\geq 25.8$ & 163 & 997.3 & 38 & 1.37 & $0.83-2.25$ & & 1.46 & $0.87-2.44$ & \\
\hline$p$ for trend & & & & & & 0.35 & & & 0.59 \\
\hline$p$ for trend in women wit & $M I \geq 21.2$ & & & & & 0.18 & & & 0.11 \\
\hline Premenopausal & & & & & & & & & \\
\hline$<21.2$ & 89 & 556.1 & 18 & 2.04 & $0.88-4.69$ & & 1.75 & $0.71-4.29$ & \\
\hline$\geq 21.2$ to $<23.3$ & 73 & 510.2 & 8 & 1.00 & ference) & & 1.00 & ference) ${ }^{b}$ & \\
\hline$\geq 23.3$ to $<25.8$ & 63 & 391.6 & 11 & 1.74 & $0.70-4.35$ & & 1.61 & $0.63-4.11$ & \\
\hline$\geq 25.8$ & 52 & 319.8 & 13 & 2.49 & $1.03-6.03$ & & 2.61 & $1.01-6.78$ & \\
\hline$p$ for trend & & & & & & 0.52 & & & 0.29 \\
\hline $\mathrm{p}$ for trend in women wit & $M I \geq 21.2$ & & & & & 0.05 & & & 0.059 \\
\hline Postmenopausal & & & & & & & & & \\
\hline$<21.2$ & 67 & 371.6 & 20 & 1.56 & $0.82-2.98$ & & 0.93 & $0.47-1.86$ & \\
\hline$\geq 21.2$ to $<23.3$ & 86 & 500.7 & 17 & 1.00 & fference) & & 1.00 & ference) $^{b}$ & \\
\hline$\geq 23.3$ to $<25.8$ & 93 & 589.2 & 16 & 0.74 & $0.37-1.47$ & & 0.45 & $0.21-0.94$ & \\
\hline$\geq 25.8$ & 108 & 670.7 & 22 & 0.93 & $0.49-1.75$ & & 0.72 & $0.36-1.45$ & \\
\hline$p$ for trend & & & & & & 0.086 & & & 0.2 \\
\hline $\mathrm{p}$ for trend in women wit & $M I \geq 21.2$ & & & & & 0.91 & & & 0.71 \\
\hline Pre $v$ Post $p$ for heterogeneity of $t$ & & & & & & 0.13 & & & 0.24 \\
\hline Pre $v$ Post $p$ for heterogeneity of $t$ & ds in women & $\mathrm{BMI} \geq 21.2$ & & & & 0.09 & & & 0.11 \\
\hline
\end{tabular}

${ }^{a}$ Adjusted by age, stage (in situ or localized, lymph node metastasis, local invasion, distant metastasis, missing), hormone receptor (ER + or PgR+, ER-/PgR-, missing), radiation therapy (no, yes), chemotherapy (no, yes), endocrine therapy (no, yes), smoking (current, past, never, missing), family history of breast cancer in father, mother, brother or sister (no, yes), menopausal status (premenopausal, postmenopausal, missing), physical activity (almost no, more than one hour per week, missing) and comorbidities (no, yes).

${ }^{b}$ Adjusted by age, stage, hormone receptor, radiation therapy, chemotherapy, endocrine therapy, smoking, family history of breast cancer in father, mother, brother or sister, physical activity and comorbidities.

An increased risk of all-cause death was found among premenopausal women with $\mathrm{BMI} \geq 25.8 \mathrm{~kg} / \mathrm{m}^{2}$. Trend test for premenopausal women with $\mathrm{BMI} \geq 21.2 \mathrm{~kg} / \mathrm{m}^{2}$ also showed a marginal dose-response relationship.

ER/PR status (Table 4). Among women with ER+or PgR + tumors, BMI was significantly associated with both all-cause (multivariate-adjusted $\mathrm{p}$ for trend=0.02) and breast cancer-specific death (multivariate-adjusted $\mathrm{p}$ for trend $=0.031$ ) if the women had a BMI of $\geq 21.2 \mathrm{~kg} / \mathrm{m}^{2}$. Heavier women $\left(\geq 25.8 \mathrm{~kg} / \mathrm{m}^{2}\right)$ with $\mathrm{ER}+$ or PgR + tumors showed a higher risk of breast cancer-specific death (4.95, 1.05-23.35). BMI $<21.2 \mathrm{~kg} / \mathrm{m}^{2}$ carried a higher risk of all-cause $(2.91,1.09-7.77)$ and breast cancer-specific death $(7.23,1.57-33.34)$ compared to women with BMI $\geq 21.2$ to $<23.3 \mathrm{~kg} / \mathrm{m}^{2}$. No significant association between BMI and all-cause and breast cancer-specific death was found for ER-/PgR- tumors. For all-cause and breast cancer-specific death, the trends were not significantly different between ER+ or PgR + and ER-/PgRwomen with $\mathrm{BMI} \geq 21.2 \mathrm{~kg} / \mathrm{m}^{2}$ ( $\mathrm{P}$ for heterogeneity of trends $=0.10$ and 0.13 , respectively).

\section{Discussion}

This study demonstrated that higher BMI was significantly associated with all-cause death among premenopausal patients after adjustment for clinical and known factors that are associated with the mortality risk of breast cancer patients. Analysis stratified according to hormonal receptor status showed that higher and lower BMI were associated with increased risks of all-cause and breast cancer-specific death only for patients with $\mathrm{ER}+$ or PgR + tumors. Previous studies that investigated the relationship between BMI and outcome in Japanese breast cancer patients considered only a few known risk factors as covariates, included only a small number of cases, and did not assess hormone receptor status $[25,26]$. Our study is of importance in having assessed the relationship between BMI and all-cause or breast cancer-specific death by taking into account multiple risk 
Table 3 HR $(95 \% \mathrm{Cl})$ of breast cancer-specific death associated with BMI overall and by menopausal status

\begin{tabular}{|c|c|c|c|c|c|c|c|c|c|}
\hline BMI & Patients & Person- & Breast cancer- & Age- & usted & & Mult & te-adjusted & \\
\hline & & years & specific death & & $95 \% \mathrm{Cl}$ & & & $95 \% \mathrm{Cl}$ & \\
\hline All & & & & & & & & & \\
\hline$<21.2$ & 163 & 963.0 & 34 & 1.69 & $0.98-2.92$ & & 1.59 & $0.90-2.81$ & \\
\hline$\geq 21.2$ to $<23.3$ & 166 & 1052.4 & 21 & 1.00 & rence) & & 1.00 & ence) ${ }^{a}$ & \\
\hline$\geq 23.3$ to $<25.8$ & 161 & 1020.1 & 26 & 1.32 & $0.74-2.35$ & & 1.20 & $0.66-2.17$ & \\
\hline$\geq 25.8$ & 163 & 997.3 & 27 & 1.40 & $0.79-2.49$ & & 1.46 & $0.81-2.64$ & \\
\hline $\mathrm{p}$ for trend & & & & & & 0.64 & & & 0.87 \\
\hline $\mathrm{p}$ for trend in women $\mathrm{v}$ & $\mathrm{BMI} \geq 21.2$ & & & & & 0.20 & & & 0.18 \\
\hline Premenopausal & & & & & & & & & \\
\hline$<21.2$ & 89 & 556.1 & 15 & 1.60 & $0.68-3.80$ & & 1.22 & $0.47-3.14$ & \\
\hline$\geq 21.2$ to $<23.3$ & 73 & 510.2 & 8 & 1.00 & rence) & & 1.00 & nce) ${ }^{b}$ & \\
\hline$\geq 23.3$ to $<25.8$ & 63 & 391.6 & 11 & 1.77 & $0.71-4.41$ & & 1.62 & $0.63-4.20$ & \\
\hline$\geq 25.8$ & 52 & 319.8 & 10 & 1.95 & $0.77-4.96$ & & 1.68 & $0.61-4.65$ & \\
\hline $\mathrm{p}$ for trend & & & & & & 0.48 & & & 0.34 \\
\hline $\mathrm{p}$ for trend in women $\mathrm{v}$ & $\mathrm{BMI} \geq 21.2$ & & & & & 0.18 & & & 0.51 \\
\hline Postmenopausal & & & & & & & & & \\
\hline$<21.2$ & 67 & 371.6 & 15 & 1.89 & $0.87-4.11$ & & 1.22 & $0.52-2.86$ & \\
\hline$\geq 21.2$ to $<23.3$ & 86 & 500.7 & 11 & 1.00 & rence) & & 1.00 & $n(e))^{b}$ & \\
\hline$\geq 23.3$ to $<25.8$ & 93 & 589.2 & 13 & 1.09 & $0.49-2.45$ & & 0.79 & $0.32-1.93$ & \\
\hline$\geq 25.8$ & 108 & 670.7 & 14 & 1.02 & $0.46-2.26$ & & 1.03 & $0.43-2.50$ & \\
\hline $\mathrm{p}$ for trend & & & & & & 0.15 & & & 0.56 \\
\hline$p$ for trend in women $v$ & $\mathrm{BMI} \geq 21.2$ & & & & & 0.86 & & & 0.45 \\
\hline Pre $\vee$ Post $\mathrm{p}$ for heterogeneity & trends & & & & & 0.13 & & & 0.27 \\
\hline Pre $v$ Post $p$ for heterogeneity & trends in $\mathrm{w}$ & en with $B$ & $\geq 21.2$ & & & 0.29 & & & 0.80 \\
\hline
\end{tabular}

${ }^{a}$ Adjusted by age, stage (in situ or localized, lymph node metastasis, local invasion, distant metastasis, missing), hormone receptor (ER + or PgR+, ER-/PgR-, Missing), radiation therapy (no, yes), chemotherapy (no, yes), endocrine therapy (no, yes), smoking (current, past, never, missing), family history of breast cancer in father, mother, brother or sister (no, yes), menopausal status (premenopausal, postmenopausal, missing), physical activity (almost no, more than one hour per week, missing) and comorbidities (no, yes).

${ }^{b}$ Adjusted by age, stage, hormone receptor, radiation therapy, chemotherapy, endocrine therapy, smoking, family history of breast cancer in father, mother, brother or sister, physical activity and comorbidities.

No dose-response relationship between BMI and breast cancer-specific death was found.

factors for breast cancer, in addition to menopausal status and hormone receptor status, in Japanese women.

Our results demonstrated that higher BMI was significantly associated with all-cause death among premenopausal patients, and were consistent with several previous observational studies of premenopausal or younger women that demonstrated poorer overall survival with increased BMI $[2,4,17,18,20]$. A meta-analysis including 43 studies showed that the effect of obesity on higher all-cause or breast cancer-specific death was larger among premenopausal than among postmenopausal women [21]. Our present results demonstrated that the effect of higher BMI was greater for all-cause death than for breast cancer-specific death $(\mathrm{HR}=2.61 ; 95 \% \mathrm{CI}$ : 1.01-6.78 for BMI $\geq 25.8 \mathrm{~kg} / \mathrm{m}^{2}$ for all-cause death; $\mathrm{HR}=$ 1.68; $95 \%$ CI: $0.61-4.65$ for BMI $\geq 25.8 \mathrm{~kg} / \mathrm{m}^{2}$ for breast cancer-specific death). One possibility is that women with higher BMI have poorer overall survival because of a higher risk of comorbidities. Therefore, we reanalyzed the data after excluding patients who had comorbidities. Within the limited statistical power, the effect of higher BMI was significant for all-cause death among premenopausal patients $(\mathrm{HR}=3.42$; 95\% CI: $1.23-9.47$ for BMI $\geq 25.8 \mathrm{~kg} / \mathrm{m}^{2}$ for all-cause death, $\mathrm{p}$ for trend for BMI $\geq 21.2 \mathrm{~kg} / \mathrm{m}^{2}=0.0068$ ) and not significant for breast cancer-specific death. These were perhaps potential mediators of the adverse effect of higher BMI in premenopausal breast cancer patients, independent of comorbidities.

In the present study, an association of higher BMI with poorer outcome was seen in women with ER + or PgR + tumors. This result is consistent with previous studies that have indicated an association of higher BMI with poorer outcome, being especially pronounced among 
Table 4 HR $(95 \% \mathrm{Cl})$ of all-cause and breast cancer-specific death associated with BMI by hormone receptor status

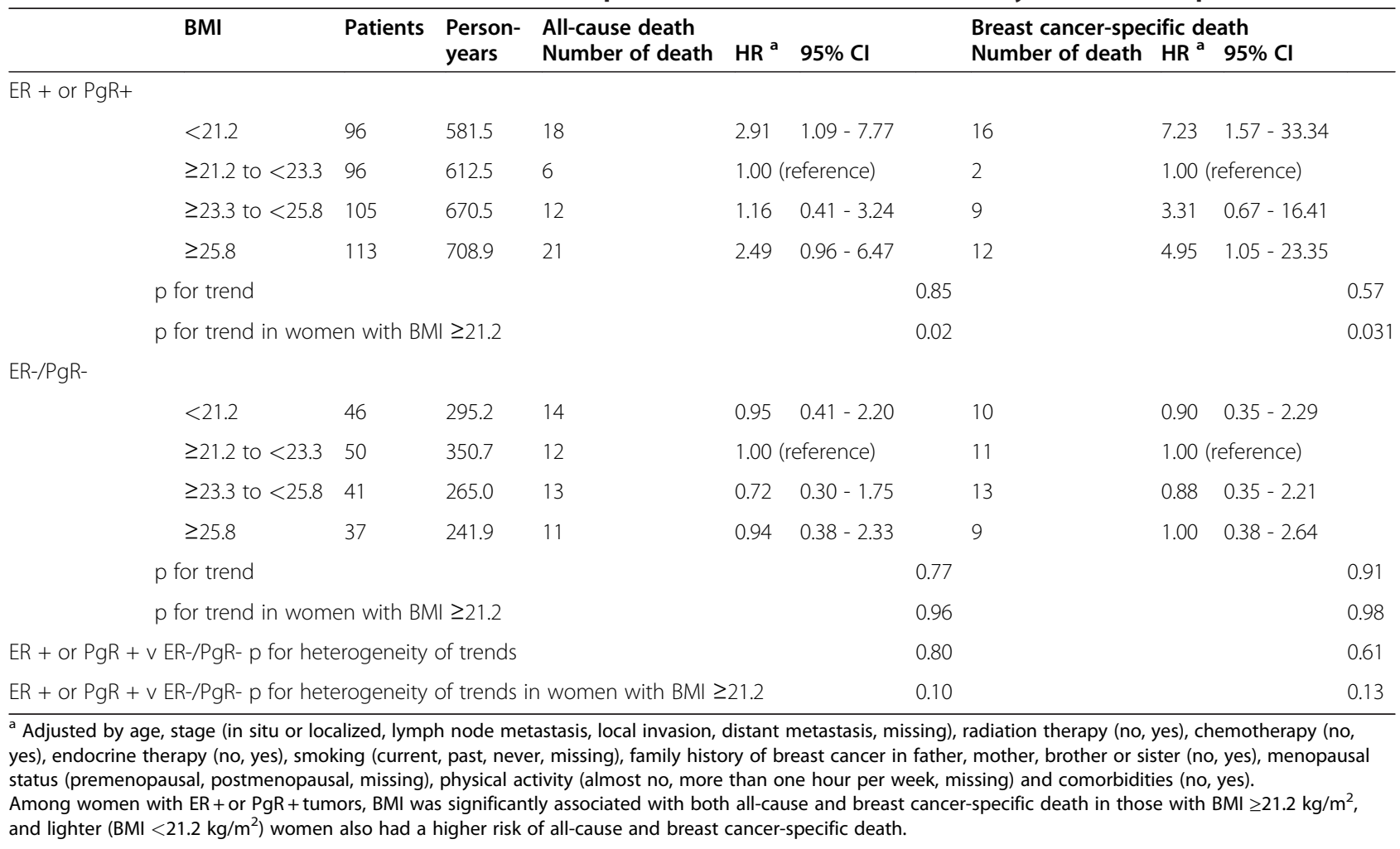

women with hormone receptor-positive tumors $[9,10]$. Several hypotheses to explain why obese breast cancer patients show poorer survival can be considered. Firstly, there may be differences in sensitivity to estrogen among tumors with different types of hormone receptors. A previous study found that hormone receptor-positive tumors showed a better response to endocrine therapy than ER-/PgR- tumors [34], indicating that ER + or PgR + tumors are the most sensitive to estrogen hormone. Secondly, it has been postulated that higher estrogen concentrations may confer increased biological aggressiveness on hormone receptor-positive tumors, as BMI is directly related to circulating estrogen levels $[22,35,36]$. Thirdly, higher BMI is associated with upregulation of a number of cellular proliferation pathways [37]. Consequently, obesity might lead to an increase of tumor cell proliferation and metastasis through undefined adipokine effects on tumor cells [17]. For example, leptin, an adipocytokine, is produced mainly by adipose tissue and is known to act as a cancer growth factor [38], as well as promoting angiogenesis and potentially stimulating the growth of breast cancer cells, thus possibly leading to reduced patient survival [39].

Our present multivariate-adjusted analysis showed that BMI $<21.2 \mathrm{~kg} / \mathrm{m}^{2}$, i.e. low BMI, was associated with elevated risks of both all-cause and breast cancer-specific death among women with ER + or PgR + tumors. The relationship between low BMI and higher cancer mortality risk might be at least partly explained by the presence of circulating tumor cells (CTCs) in the peripheral blood of patients [40]. CTCs are derived from clones in the primary tumor [41] and are thought to become scattered to various organs, leading to the development of distant metastasis [42]. In patients showing chronic undernutrition, cytokine reactions and subsequent activation of the immune system are compromised, which might affect the tumor-immune system interaction in distant organs [43]. In this study, the BMI $<21.2 \mathrm{~kg} / \mathrm{m}^{2}$ category might have included undernourished patients as well as properly nourished, naturally lean patients. This may have partly contributed to the increased risk of all-cause and breast cancer-specific death. Another reason for the relationship between the BMI $<21.2 \mathrm{~kg} / \mathrm{m}^{2}$ category and higher risk of cancer mortality might have been the slightly higher proportion of patients with advancedstage breast cancer. Therefore, we attempted to analyze the data by omitting cases of advanced breast cancer. However, this analysis yielded almost the same results (data not shown).

The major strengths of the present study were that no subject was lost to follow-up during the study period. The MCCH Cancer Registry conducts active follow-up by accessing hospital visit records, resident registration cards and permanent domicile data. In cases of death occurring outside the hospital, information on the date and cause of death was obtained with permission from the 
Ministry of Justice. Another strength was the relatively low proportion of patients for whom data on hormone receptor status were missing (10.6\%). In previous studies, the proportion of patients for whom data on ER and/or PgR status were missing ranged from $5.0 \%$ to $48.1 \%$ $[2,4,9,10]$. Distribution of receptor status for ER and PgR was roughly the same as those in previous studies which investigated 3,089 patients from ten hospitals in Japan [44]. A further strength was that it gave consideration not only to clinical stages but also to treatments such as chemotherapy, endocrine therapy and radiation therapy from an epidemiological viewpoint.

Several limitations of our study should also be considered. First, although BMI has been accepted as an index of obesity, it cannot be used to identify the distributions of fat and muscle tissue. Second, we used self-reported BMI at the baseline, and there may have been a misclassification of exposure due to self-reported weight and height. However, the self-reported current height and weight data were highly correlated with measured data, and therefore any possible bias was likely small. Third, stratification by hormone receptor status may have resulted in false positive or false negative results. The 95\% CIs were wide for HRs by hormone receptor status, suggesting that statistical power might be limited because of relatively small number of patients and all-cause and breast cancer-specific deaths. To obtain reliable results with this stratification, subsequent recruitment of patients and follow-up will be required. Fourth, the generalizability of our results to the Japanese population as whole may be limited because our study was conducted among a population living in a rural area. More studies are needed to verify our results instead of to assess the generalizability.

\section{Conclusions}

In conclusion, being obese is a risk factor for all-cause death in premenopausal women and a risk factor for allcause and breast cancer-specific death in patients with $\mathrm{ER}+$ or PgR + tumors. Lower BMI is associated with higher all-cause and breast cancer-specific death in patients with ER + or PgR + tumors. As higher and lower BMI are directly related to mortality [45], it is important to maintain an appropriate body weight for height.

\footnotetext{
Abbreviations

MCCH: Miyagi Cancer Center Hospital; ER: Estrogen receptor;

PgR: Progesterone receptor; ElA: Enzyme immunoassay;

IHC: Immunohistochemistry; HSCORE: Histology score; HR: Hazard ratio;

$\mathrm{Cl}$ : Confidence interval; CTC: Circulating tumor cell.
}

\section{Competing interests}

The authors declare that they have no competing interests.

\section{Authors' contributions}

MK, YM, YN, YK participated in the design of the study. MK, YM participated in the statistical analysis of the data. MK, YM, KF, YN, NO, YK drafted the manuscript. MK, YM, KF, YN, YK participated in the collection of the data. All authors read and approved the final manuscript.

\section{Acknowledgements}

This work was supported by Grants-in-Aid from the Japan Society for the Promotion of Science (JSPS) for Scientific Research (B) (23390169) and for Young Scientists (B) (22790031), and by the 3 rd Term Comprehensive Control Research for Cancer [grant number H23-Sanjigan-shitei-002] from the Ministry of Health, Labour and Welfare of Japan.

\section{Author details}

'Division of Community Health, Tohoku University Graduate School of Medicine, 2-1 Seiryo-machi, Aoba-ku, Sendai, Miyagi980-8575, Japan. ²Division of Cancer Epidemiology and Prevention, Miyagi Cancer Center Research Institute, 47-1 Nodayama, Medeshima-Shiode, Natori, Miyagi981-1293, Japan. ${ }^{3}$ Department of Breast Oncology, Miyagi Cancer Center Hospital, 47-1 Nodayama, Medeshima-Shiode, Natori, Miyagi981-1293, Japan. ${ }^{4}$ Department of Surgical Oncology, Tohoku University Graduate School of Medicine, 1-1 Seiryo-machi, Aoba-ku, Sendai, Miyagi980-8574, Japan.

Received: 9 December 2011 Accepted: 3 April 2012

Published: 17 April 2012

\section{References}

1. American Institute for Cancer Research., World Cancer Research Fund.: Food, nutrition, physical activity and the prevention of cancer : a global perspective : a project of World Cancer Research Fund International Washington, D.C.: American Institute for Cancer Research; 2007.

2. Berclaz G, Li S, Price KN, Coates AS, Castiglione-Gertsch M, Rudenstam CM, Holmberg SB, Lindtner J, Erien D, Collins J, et al: Body mass index as a prognostic feature in operable breast cancer: the International Breast Cancer Study Group experience. Ann Oncol 2004, 15:875-884.

3. Dawood S, Broglio K, Gonzalez-Angulo AM, Kau SW, Islam R, Hortobagyi GN, Cristofanilli M: Prognostic value of body mass index in locally advanced breast cancer. Clin Cancer Res 2008, 14:1718-1725.

4. Loi S, Milne RL, Friedlander ML, McCredie MR, Giles GG, Hopper JL, Phillips KA: Obesity and outcomes in premenopausal and postmenopausal breast cancer. Cancer Epidemiol Biomarkers Prev 2005, 14:1686-1691.

5. Chang S, Alderfer JR, Asmar L, Buzdar AU: Inflammatory breast cancer survival: The role of obesity and menopausal status at diagnosis. Breast Cancer Res Tr 2000, 64:157-163.

6. Eley JW, Hill HA, Chen WW, Austin DF, Wesley MN, Muss HB, Greenberg RS, Coates RJ, Correa P, Redmond CK, et al: Racial differences in survival from breast cancer. Results of the National Cancer Institute Black/White Cancer Survival Study. JAMA 1994, 272:947-954.

7. Coates RJ, Clark WS, Eley JW, Greenberg RS, Huguley CM Jr, Brown RL: Race, nutritional status, and survival from breast cancer. J Natl Cancer Inst 1990, 82:1684-1692.

8. Tretli S, Haldorsen T, Ottestad L: The effect of pre-morbid height and weight on the survival of breast cancer patients. Br J Cancer 1990, 62:299-303.

9. Maehle $\mathrm{BO}$, Tretli S: Pre-morbid body-mass-index in breast cancer: reversed effect on survival in hormone receptor negative patients. Breast Cancer Res Treat 1996, 41:123-130.

10. Barnett GC, Shah M, Redman K, Easton DF, Ponder BA, Pharoah PD: Risk factors for the incidence of breast cancer: do they affect survival from the disease? J Clin Oncol 2008, 26:3310-3316.

11. Petrelli JM, Calle EE, Rodriguez C, Thun MJ: Body mass index, height, and postmenopausal breast cancer mortality in a prospective cohort of US women. Cancer Causes Control 2002, 13:325-332.

12. Cleveland RJ, Eng SM, Abrahamson PE, Britton JA, Teitelbaum SL, Neugut Al, Gammon MD: Weight gain prior to diagnosis and survival from breast cancer. Cancer Epidemiol Biomarkers Prev 2007, 16:1803-1811.

13. Reeves KW, Faulkner K, Modugno F, Hillier TA, Bauer DC, Ensrud KE, Cauley $J A$ : Body mass index and mortality among older breast cancer survivors in the Study of Osteoporotic Fractures. Cancer Epidemiol Biomarkers Prev 2007, 16:1468-1473.

14. de Azambuja E, McCaskill-Stevens W, Francis P, Quinaux E, Crown JP, Vicente M, Giuliani R, Nordenskjold B, Gutierez J, Andersson M, et al: The effect of body mass index on overall and disease-free survival in node-positive breast cancer patients treated with docetaxel and doxorubicin- 
containing adjuvant chemotherapy: the experience of the BIG 02-98 trial. Breast Cancer Res Treat 2010, 119:145-153.

15. Abrahamson PE, Gammon MD, Lund MJ, Flagg EW, Porter PL, Stevens J, Swanson CA, Brinton LA, Eley JW, Coates RJ: General and abdominal obesity and survival among young women with breast cancer. Cancer Epidemiol Biomarkers Prev 2006, 15:1871-1877.

16. Nichols HB, Trentham-Dietz A, Egan KM, Titus-Ernstoff L, Holmes MD, Bersch AJ, Holick CN, Hampton JM, Stampfer MJ, Willett WC, et al: Body mass index before and after breast cancer diagnosis: associations with allcause, breast cancer, and cardiovascular disease mortality. Cancer Epidemiol Biomarkers Prev 2009, 18:1403-1409.

17. Daling JR, Malone KE, Doody DR, Johnson LG, Gralow JR, Porter PL: Relation of body mass index to tumor markers and survival among young women with invasive ductal breast carcinoma. Cancer 2001, 92:720-729.

18. Hebert JR, Hurley TG, Ma Y: The effect of dietary exposures on recurrence and mortality in early stage breast cancer. Breast Cancer Res Treat 1998, 51:17-28.

19. Holmberg L, Lund E, Bergstrom R, Adami HO, Meirik O: Oral contraceptives and prognosis in breast cancer: effects of duration, latency, recency, age at first use and relation to parity and body mass index in young women with breast cancer. Eur J Cancer 1994, 30A:351-354.

20. Lu Y, Ma H, Malone KE, Norman SA, Sullivan-Halley J, Strom BL, Marchbanks PA, Spirtas R, Burkman RT, Deapen D, et al: Obesity and survival among black women and white women 35 to 64 years of age at diagnosis with invasive breast cancer. J Clin Oncol 2011, 29:3358-3365.

21. Protani M, Coory M, Martin JH: Effect of obesity on survival of women with breast cancer: systematic review and meta-analysis. Breast Cancer Res Treat 2010, 123:627-635.

22. Siiteri PK: Adipose tissue as a source of hormones. Am J Clin Nutr 1987 , 45:277-282

23. Sorlie T, Tibshirani R, Parker J, Hastie T, Marron JS, Nobel A, Deng S, Johnsen $H$, Pesich R, Geisler S, et al: Repeated observation of breast tumor subtypes in independent gene expression data sets. Proc Natl Acad SC USA 2003, 100:8418-8423.

24. Yamashita H, Iwase H, Toyama T, Takahashi S, Sugiura H, Yoshimoto N, Endo Y, Fujii Y, Kobayashi S: Estrogen receptor-positive breast cancer in Japanese women: trends in incidence, characteristics, and prognosis. Ann Oncol 2011, 22:1318-1325.

25. Abe R, Kumagai N, Kimura M, Hirosaki A, Nakamura T: Biological characteristics of breast cancer in obesity. Tohoku J Exp Med 1976, 120:351-359.

26. Kyogoku S, Hirohata T, Takeshita S, Nomura Y, Shigematsu T, Horie A Survival of breast-cancer patients and body size indicators. Int J Cancer 1990, 46:824-831.

27. Minami $\mathrm{Y}$, Tateno $\mathrm{H}$ : Associations between cigarette smoking and the risk of four leading cancers in Miyagi Prefecture, Japan: a multi-site case-control study. Cancer Sci 2003, 94:540-547.

28. Minami $Y$, Tochigi T, Kawamura S, Tateno H, Hoshi S, Nishino Y, Kuwahara M: Height, urban-born and prostate cancer risk in Japanese men. Jpn J Clin Oncol 2008, 38:205-213.

29. Kakugawa $Y$, Minami $Y$, Tateno $H$, Inoue $H$, Fujiya $T$ : Relation of serum levels of estrogen and dehydroepiandrosterone sulfate to hormone receptor status among postmenopausal women with breast cancer. Breast Cancer 2007, 14:269-276.

30. Cox DR: Regression models and life-tables (with discussion). Journal of the Royal Statistical Society 1972, 34:187-220.

31. Kawai M, Minami Y, Kakizaki M, Kakugawa Y, Nishino Y, Fukao A, Tsuji I, Ohuchi N: Alcohol consumption and breast cancer risk in Japanese women: The Miyagi Cohort Study. Breast Cancer Res Treat 2011, 128:817-825.

32. Kawai M, Minami Y, Kuriyama S, Kakizaki M, Kakugawa Y, Nishino Y, Ishida T, Fukao A, Tsuji I, Ohuchi N: Adiposity, adult weight change and breast cancer risk in postmenopausal Japanese women: the Miyagi Cohort Study. Br J Cancer 2010, 103:1443-1447.

33. Kawai M, Minami $Y$, Kuriyama S, Kakizaki M, Kakugawa $Y$, Nishino $Y$, Ishida $T$ Fukao A, Tsuji I, Ohuchi N: Reproductive factors, exogenous female hormone use and breast cancer risk in Japanese: the Miyagi Cohort Study. Cancer Causes Control 2010, 21:135-145.

34. Yamashita $H$, Yando $Y$, Nishio M, Zhang Z, Hamaguchi M, Mita K, Kobayashi S, Fujii Y, Iwase H: Immunohistochemical evaluation of hormone receptor status for predicting response to endocrine therapy in metastatic breast cancer. Breast Cancer 2006, 13:74-83.

35. Potischman N, Swanson CA, Siiteri P, Hoover RN: Reversal of relation between body mass and endogenous estrogen concentrations with menopausal status. J Nat/ Cancer Inst 1996, 88:756-758.

36. Bulun SE, Lin Z, Imir G, Amin S, Demura M, Yilmaz B, Martin R, Utsunomiya $H$, Thung $S$, Gurates $B$, et al: Regulation of aromatase expression in estrogen-responsive breast and uterine disease: from bench to treatment. Pharmacol Rev 2005, 57:359-383.

37. Calle EE, Kaaks R: Overweight, obesity and cancer: epidemiological evidence and proposed mechanisms. Nat Rev Cancer 2004, 4:579-591.

38. Somasundar P, McFadden DW, Hileman SM, Vona-Davis L: Leptin is a growth factor in cancer. J Surg Res 2004, 116:337-349.

39. Hu X, Juneja SC, Maihle NJ, Cleary MP: Leptin-a growth factor in normal and malignant breast cells and for normal mammary gland development. J Natl Cancer Inst 2002, 94:1704-1711.

40. Ashworth TR: A case of cancer in which cells similar to those in the tumours were seen in the blood after death. Aust Med J 1869, 14:146-147.

41. Tokudome N, Ito Y, Takahashi S, Kobayashi K, Taira S, Tsutsumi C, Oto M, Oba M, Inoue K, Kuwayama A, et al: Detection of circulating tumor cells in peripheral blood of heavily treated metastatic breast cancer patients. Breast Cancer 2011, 18:195-202.

42. Paget S: The distribution of secondary growths in cancer of the breast. Lancet 1889, 1:571-573.

43. Cunningham-Rundles S, McNeeley DF, Moon A: Mechanisms of nutrient modulation of the immune response. J Allergy Clin Immunol 2005, 115:1119-1128. quiz 1129.

44. Nomura Y, Miura S, Koyama H, Enomoto K, Kasumi F, Yamamoto H, Kimura $M$, Tominaga $T$, lino $H$, Morimoto $T$, et al: Relative effect of steroid hormone receptors on the prognosis of patients with operable breast cancer. A univariate and multivariate analysis of 3089 Japanese patients with breast cancer from the Study Group for the Japanese Breast Cancer Society on Hormone Receptors and Prognosis in Breast Cancer. Cancer 1992, 69:153-164.

45. Nagai M, Kuriyama S, Kakizaki M, Ohmori-Matsuda K, Sugawara $Y$, Sone T, Hozawa A, Tsuji I: Effect of age on the association between body mass index and all-cause mortality: the Ohsaki cohort study. J Epidemiol 2010, 20:398-407.

doi:10.1186/1471-2407-12-149

Cite this article as: Kawai et al:: Body mass index and survival after breast cancer diagnosis in Japanese women. BMC Cancer 2012 12:149.

\section{Submit your next manuscript to BioMed Central and take full advantage of:}

- Convenient online submission

- Thorough peer review

- No space constraints or color figure charges

- Immediate publication on acceptance

- Inclusion in PubMed, CAS, Scopus and Google Scholar

- Research which is freely available for redistribution 